\title{
Alternative disease management strategies for organic apple production in the United Kingdom
}

\author{
Lucas Alexander Shuttleworth* (1)
}

\begin{abstract}
Apple is a globally important tree fruit. In the United Kingdom (UK) and mainland Europe, there is ongoing consumer and environmental concern regarding over-reliance on conventional chemicals for disease control. This has resulted in an increase in withdrawal of active ingredients and legal use restrictions over recent years. The loss of active ingredients can be problematic for growers, who have relied on the generally more predictable and efficacious management that results from using conventional chemicals. Organic disease management methods are generally more sustainable over the long term as organic methods have fewer negative impacts on the environment and on human health. Key diseases of organic UK apple production include scab, European canker, powdery mildew, apple replant disease, and brown rot/blossom wilt. The recommended organic control measures depend on the disease. Measures range from the use of host resistance, rootstock and scion cultivar selection, planting location of trees, application of biological control agents, soil amendments, cultural management, postharvest treatments, disease modelling and forecasting. The challenge when using organic methods is results are often more variable and less predictable than when using conventional chemicals. Biological control agents, for example, often require more applications than chemicals, need correct timing to work effectively, and can be sensitive to weather and orchard management. Additionally, a thorough understanding of disease ecology by growers is helpful for more effective implementation of organic control methods. Invasive pathogens not currently present in the UK that may affect apple production including Xylella fastidiosa and Valsa mali, and the potential effects of climate change on pathogens already present such as Erwinia amylovora (fireblight) are discussed. The consequences of climate change are difficult to predict due to the changeable nature of the weather and the variation in factors contributing to climate change. However, a warming planet and more unpredictable weather patterns may favour range expansion of pathogens, while increasing plant stress and susceptibility. This review presents various methods that can be applied as alternatives to conventional chemicals for disease control in organic apple production to provide economic efficiency, environmental sustainability, and the supply of safe nutritious food.
\end{abstract}

Keywords: Biological control agents, Integrated disease management

*Correspondence: lucasashuttleworth@gmail.com NIAB EMR, Department of Pest and Pathogen Ecology, East Malling, Kent ME196BJ, UK

\section{Background}

Apple is a globally important tree fruit. In 2019, the value of dessert and culinary apple production in the United Kingdom (UK) was $£ 183$ million (Department of Environment, Food \& Rural Affairs 2020a). In the UK and mainland Europe, there is ongoing consumer and environmental concerns regarding over-reliance on 
conventional chemicals for pest and disease management. This has resulted in withdrawal of many products and ongoing restrictions on the use of many others.

The European Commission (EC) defines organic farming as an agricultural method that aims to produce food using natural substances and processes (European Commission 2020). The EC states organic farming tends to have a limited environmental impact as it encourages (1) the responsible use of energy and natural resources; (2) the maintenance of biodiversity; (3) preservation of regional ecological balances; (4) enhancement of soil fertility; and (5) the maintenance of water quality.

European Union (EU) regulations on organic farming were designed to provide a clear structure for the production of organic products across the EU. This is to satisfy consumer demand for trustworthy organic products whilst providing a fair marketplace for producers, distributors and marketers. All organic food and drink sold in the EU must meet the EU Organic Regulation standards.

There are several approved organic bodies in the UK including the Organic Farmers \& Growers CIC (GBORG-02), the Organic Food Federation (GB-ORG-04), the Soil Association Certification Ltd (GB-ORG-05), the Biodynamic Association Certification (GB-ORG-06), the Quality Welsh Food Certification Ltd (GB-ORG-13), and the OF\&G (Scotland) Ltd (GB-ORG-17). It is a requirement that the identifying code of the certifier must be used when labelling certified organic products, for example 'Organic Certification: GB-ORG-01'. The name, initials or logo of the certifier can also be used in addition to the code. An example of the organic farming standards in the UK can be accessed from the Soil Association (2021). To incentivise organic tree fruit production in the UK, the UK government offers country stewardship grants for organic tree fruit production and conversion of tree fruit orchards to organic production.

In the UK, the Agriculture and Horticulture Development Board (AHDB) funded the Sustainable Crop and Environment Protection-Target Research for Edibles (SCEPTRE) and SCEPTREplus projects 'Research for sustainable plant protection products for use in horticulture' that facilitate delivery of research testing sustainable plant protection products for use on high priority disease, pest and weed problems in horticulture and ornamental production. The projects also support the approval of products and help to develop integrated pest and disease management programmes for industry. The projects are managed by a consortium of scientific researchers and consultants from the University of Warwick, the Agricultural Development and Advisory Service (ADAS), the National Institute of Agricultural Botany Cambridge (NIAB), the National Institute of Agricultural Botany
East Malling Research (NIAB EMR), Biorationale Ltd and AHDB.

The Apple Best Practice Guides published by the AHDB reviewed the key diseases afflicting UK tree fruit production (AHDB 2020a, b, c, d, e, f, g). Some of the information needs updating, particularly concerning alternative products. The primary objective of this article is to review viable alternative management methods for organic apple production including novel and alternative management that will aid both organic and conventional growers. The review will also identify areas for further research.

The key diseases of organic UK apple production and alternative management for their control that are considered include apple scab, European canker, powdery mildew, apple replant disease (ARD), and brown rot/ blossom wilt (Fig. 1). Invasive pathogens not yet present in the UK, the potential effects of climate change on apple diseases, and future areas of research will also be discussed.

\section{Apple scab}

Apple scab is the most economically important disease of apple worldwide and is caused by the plant pathogenic fungus Venturia inaequalis. A considerable body of knowledge exists regarding the infection process and disease cycle, including the role of the overwintered sexual stage on dead leaves on the orchard floor, and the secondary infection of fruit and leaves by the asexual stage (Burchill et al. 1965; MacHardy 1996; Berrie 2019). Mycelia and conidia can overwinter in buds and twigs of the host tree and go on to produce new inoculum the following spring (Passey et al. 2017; Holb et al. 2004; Becker et al. 1992). All the major varieties grown in the UK are susceptible, especially the variety 'Gala' (Berrie 2019).

Copper applications, which may be applied at low doses, have been reported to be necessary to manage scab in organic orchards (Jamar et al. 2008). In March 2021, an emergency authorisation for FUNGURAN ${ }^{\circledR}$ PROGRESS (Certis Europe, Great Abington, UK) a copper hydroxide-based product, was made available for organic apple orchards pre bud-burst on orchards of up to 5 years of age for control of apple canker (Neonectria ditissima) (Emergency Authorisation Number: 0550 of 2021). However, the Emergency Authorisation expired on 30 April 2021.

\section{Alternatives to conventional fungicides Host resistance}

The Apple Best Practice Guide states that most of the main culinary and dessert varieties grown in UK are susceptible to scab (AHDB 2020a). According to the ten year Venturia inaequalis quest (VINQUEST) project (www. 


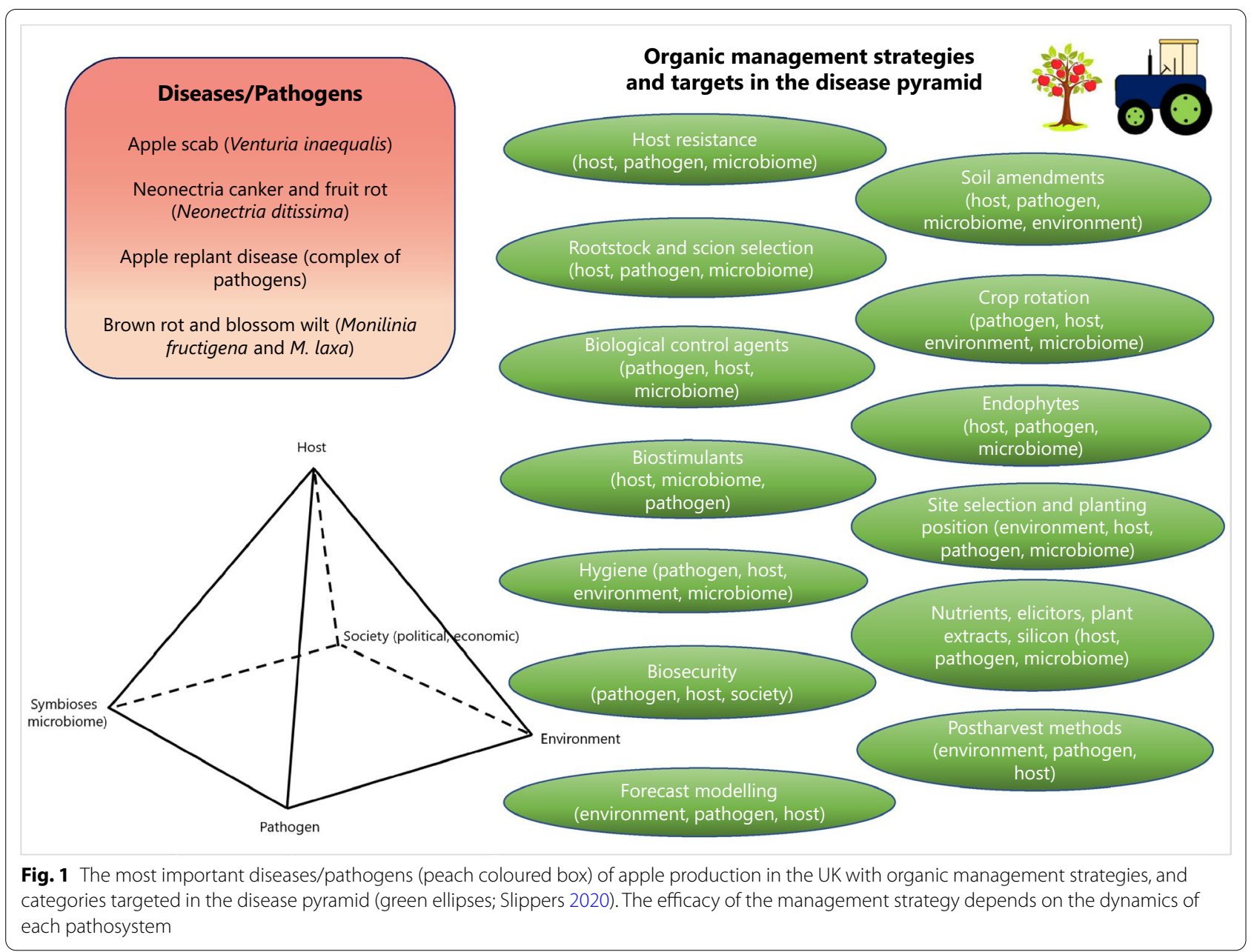

vinquest.ch), involving 24 partners from 14 countries, the most reliable solution for scab management is planting of resistant varieties (Patocchi et al. 2020). The only major resistance gene introduced into commercial apple varieties is Rvi6, which includes the commercial variety 'Topaz', popular in Germany (Passey and Xu 2019). However, breakdown of the resistance provided by Rvi6 was first observed in Europe in the 1990's and has since been reported in many European countries. The breakdown in resistance suggests that the use of a single resistance gene against scab is not a durable long-term solution. A method to achieve durable resistance is to pyramid multiple scab resistance genes in a single variety (Patocchi et al. 2020). The most promising apple-scab resistance genes for developing varieties with durable resistance are Rvi5, Rvi11, Rvi12, Rvi14 and Rvi15.

Studies have shown that orchards with a mix of scab susceptible and scab resistant varieties have less scab when compared to monocultures (Didelot et al. 2007; Bousset et al. 1997; Parisi et al. 1993). Although variety mixes have been shown to reduce scab in dessert apples, the reduction in scab is usually insufficient for commercial production standards. The magnitude of variety mixture effect depends on inoculum pressure, weather conditions, the variety mix structure and orchard management (Berrie 2019). There is possibly more scope for mixed variety plantings in organic cider production.

\section{Biological control agents and plant extracts}

There is an urgent need to develop alternative products, particularly biological based options, targeting specific stages of the $V$. inaequalis, that can be integrated with forecasting models for appropriate application timing (Berrie 2019). Biological control agents (BCAs) are reported to reduce scab, rather than control it, and may not be effective enough for use during the growing season (AHDB 2020a). There may be more scope for use of BCAs post-harvest to speed leaf decay in the orchard, and hence to reduce ascospore production. Several fungal BCAs have been reported to reduce scab under field 
conditions. Cladosporium cladosporioides H39 was found to reduce spore production and severity of scab on leaves and fruit (Köhl et al. 2009,2015). In a study of microbial antagonism against $V$. inaequalis, the fungus Chaetomium globosum was found to be most effective at reducing scab development on infected leaves, in addition to inhibiting germination and growth of the pathogen spores in vitro (Andrews 1983). A field study with C. globosum ascospore suspensions applied to apple saplings was found to reduce scab by more than $20 \%$ in a two year study (Cullen et al. 1984). In the same study, microscopic observation of leaf surfaces following inoculation of seedlings showed a $25 \%$ increase in C. globosum ascospore germination on scab-infected apple tissue when compared to healthy tissue.

A study of bacterial and yeast strains as potential BCAs against scab, found an isolate of Pseudomonas syringae that supressed scab equivalent to the chemical fungicide Captan (Burr et al. 1996). Interestingly, P. syringae has many pathogenic strains that infect horticultural trees. However, the study showed some strains may also be useful as BCAs against fungal pathogens of apple.

Plant extracts have been tested for scab management. A $1 \%$ populin [isolated from black poplar (Populus nigra)] solution, was reported to slow conidial germination of $V$. inaequalis in vitro as well as reduce scab on leaves and fruit (Bálint et al. 2014). The plant growth regulator prohexadione-ca was reported to reduce scab incidence (Bazzi et al. 2003), by inducing host resistance (Bini et al. 2008). Extracts from the soapbark tree (Quillaja saponaria), orange (Citrus sinensis) peel, grapefruit (Citrus $\times$ paradisi) seed, Mojave yucca (Yucca schidigerra), Camellia oleifera, and quinoa (Chenopodium quinoa) seeds, as well as potassium bicarbonate were reported to provide good protectant efficacy against $V$. inaequalis when applied as a 1\% solution (Jamar 2011). However, alternative methods of scab management are often not adopted by commercial growers, as the disease control provided is often variable, and the number of applications required usually outnumbers that of conventional chemicals. As with conventional chemicals, there is a chance that pathogens may develop resistance against specific active ingredients of plant extracts.

\section{Hygiene and cultural methods}

Hygiene and cultural methods are key to reducing scab in organic production, particularly where susceptible varieties are cultivated. Scab inoculum that would be produced from overwintered, scabbed leaves and twigs on the orchard floor need to be removed in autumn to prevent infection from ascospores during the following spring and summer (Passey and Xu 2019; Holb 2008). Pruning is a key strategy for scab reduction in organic production (Holb 2005). Trees should to be pruned to remove the inoculum source on infected branches, encourage good air circulation in the orchard canopy, which helps rapid drying of leaves and fruit after rain and dew (AHDB 2020a).

\section{Scab monitoring and forecasting}

It is not possible to monitor scab in the earliest period of the season, as at low temperatures it can be three weeks between infection and development of scab symptoms (Berrie and Holb 2014). Therefore, conventional fungicides are usually applied early in the season based on tree phenology and weather, rather than when scab symptoms are visible. Visual checks for scab are still important, to determine quantities of inoculum at the start of and during the season and to determine the success of management measures (Berrie 2019).

There are apple scab risk warning systems including Adem $^{\mathrm{TM}}$ that is currently being used in a recoded version by Agrii (UK) Ltd (Andoversford, Cheltenham, England), and has been used successfully to aid fungicide scheduling, resulting in reduced inputs (Berrie and Xu 2003). Metos $^{\circledR}$ (Weiz, Austria) uses the Mills or Mills/MacHardy scab infection models (Mills and LaPlante 1951; MacHardy 1996). In the UK, scab risk warnings are based mostly on the program RIMpro (Aćimović and Rosenberger 2018) and are provided by private companies at a cost. RIMpro incorporates weather forecast to assist on making decisions on treatment.

\section{European canker of apple}

Neonectria ditissima is the most important canker pathogen of apple in Europe (AHDB 2020b). The key sites for pathogen entry into trees is through wounds such as leaf scars during the autumn leaf fall period, fruit-picking scars, pruning cuts, and insect damage. In addition to cankers, the pathogen also causes fruit rots both pre and postharvest. Cankers serve as the overwintered stage of the pathogen with the wood providing a perennial substrate for survival throughout the year (Saville and Olivieri 2019).

\section{Alternatives to conventional fungicides Host resistance}

Malus species and apple varieties show variation in susceptibility to N. ditissima (Alston 1969; van de Weg 1989; Ghasemkhani et al. 2016; Gómez-Cortecero et al. 2016; Saville and Olivieri 2019). However durable host resistance to canker has yet to be demonstrated (GómezCortecero et al. 2016). Growing varieties tolerant to the disease is the most effective method of management, however, little is known regarding the genetic basis for quantitative resistance that exists in apple germplasm. 
The Biotechnology and Biological Sciences Research Council (BBSRC, Swindon, Wiltshire, England) in the UK is currently funding work investigating the genetic component of resistance through studying resistance/susceptibility in a multi-parental population at multiple sites (Harrison 2021). Resistance in the population is being assessed in both wood and fruit to examine differences in resistance in different tissues. Mapping of quantitative trait loci (QTL) for canker resistance is being completed through pedigree-based analysis, and candidate genes for resistance are being identified with transcriptomics.

\section{Rootstock and scion variety selection}

An AHDB project investigated the effect of 14 different rootstocks (grafted with Gala scion) on canker number at two sites (NIAB EMR, East Malling, Kent; and Poolhill, Newent, Gloucestershire) (AHDB TF223 2020). Canker assessments indicated the GENEVA ${ }^{\circledR}$ rootstock G.41 had the highest mean canker count (mainstem and peripheral cankers combined) at both sites, while rootstock G.11 had the second highest mean canker count at the Kent site and 6th highest at the Gloucestershire site.

The NIAB EMR elite selections EMR-003 and EMR004 had lower canker counts at both sites. However, at the Kent site, EMR-003 had the highest number of dead trees, and EMR-004 had the third highest number of dead trees. The more vigorous selection M116 had a lower canker number and a low number of dead trees at both sites, however M116 is not a feasible selection for commercial production in the UK due to its high vigour. Many other characteristics need to be taken into consideration regarding these selections in addition to canker susceptibility. Other important characteristics include fruit yield and quality, tree vigour and architecture, grafting compatibility, and tolerance to pests and other diseases.

The BBSRC LINK project 'The role of endophytes in affecting European canker development on apple' (Xu 2021) investigated the effect on canker of winter planting of trees (with spray inoculation), versus lifting, spray inoculation, refrigeration at $2{ }^{\circ} \mathrm{C}$, and planting the following spring. The commercially important varieties Gala, Kanzi, Jazz, Rubens, Golden Delicious, Grenadier and Braeburn grafted on to M9 rootstock had differing canker counts. The 2020 canker assessments showed that, across all three sites sampled and regardless of planting date, Kanzi and Jazz had higher canker counts, while Grenadier and Golden Delicious had lower canker counts. There were also site effects, with trees from the same variety planted at different locations having high canker number at one site, but low counts at another site. This indicates that site factors including orchard microclimate (temperature, rainfall, relative humidity, soil factors) affect canker.

\section{The role of endophytes}

Endophytes have been reported to influence plants in several different ways including plant growth, resistance to abiotic stress, and disease resistance (Bacon 1993; Bulgarelli et al. 2013; Busby et al. 2016). There are increasing numbers of patents for endophytic fungi (Gokhale et al. 2017). A key part of a BBSRC CankerLink project is investigating the endophyte communities in susceptible and tolerant apple varieties, and their potential in inducing or providing resistance to canker (Olivieri 2021). The study analysed fungal and bacterial endophyte communities associated with leaf scars of various scion/rootstock combinations. Site location was found to be the strongest factor affecting the fungal communities (measured by operational taxonomic units, OTUs) at the site of leaf scar tissues, followed by scion variety selection. There was little effect of rootstock tolerance on fungal endophyte communities. There were some fungal genera associated with the tolerant scion varieties which are known to contain BCAs and plant growth promoters including Aureobasidium sp. and Rhodotorula sp. However, there were also genera that contain known pathogens including Stemphylium sp. and Dissconium sp. It is not clear what role these organisms are playing, and more work needs to be done to determine their effects on canker.

\section{Biological control agents}

Trichoderma harzianum T-22 (Trianum G, Koppert Biological Systems, Haverhill, Suffolk, UK) as a soil amendment was observed to reduce canker in two of three orchard experiments (AHDB TF223 2020). A cost-benefit analysis of a newly planted orchard of 1000 trees showed a financial benefit of $>£ 1050$ over five years when using Trianum G. Other biological soil amendments including arbuscular mycorrhizal fungi (AMF) are being used to aid tree establishment. Cider apple trees inoculated with AMF have been reported to have fewer cankers than uninoculated trees (Berdeni et al. 2018). Application of an experimental plant growth promoting rhizobacteria (PGPR) product (Plantworks Ltd, Sittingbourne, Kent, UK) containing a bacterial consortium (Rhizobium sp. strain IRBG74, Bacillus amyloliquefaciens, B. megaterium, Derxia lacustris strain HL-12), showed an overall reduction in canker compared to the unamended control (AHDB TF223 2020). There was no effect on the tree vigour for any of the amendments compared to the unamended control.

Previous work on BCAs to manage $N$. ditissima have shown varying results. In a study testing more than 700 $\mathrm{BCA}$ isolates originating from apple trees and fruit, only 
four bacterial and three fungal isolates reduced canker lesions on fruit incubated at $20^{\circ} \mathrm{C}$ (Schiewe and Mendgen 1992). At $4{ }^{\circ} \mathrm{C}$, none of the BCA isolates were effective. Variation in efficacy of canker control was observed when a number of BCA products consisting either of individual strains or consortia of Bacillus spp. (B. subtilis, B. subtilis var. amyloliquefaciens), Pseudomonas putida, T. koningii, and T. harzianum were screened (Walter et al. 2017). The BCAs did not provide adequate wound protection and were not recommended during harvest and leaf fall under high spore load conditions. For efficacy, consideration needs to be given to the timing and number of applications of BCAs, and relative inoculation timing with the pathogen.

Hypoviruses and hypovirulent fungal strains have been used extensively in Europe against the chestnut blight pathogen $C$. parasitica, and may be a useful method for managing N. ditissima (Peever et al. 2000; Milgroom and Cortesi 2004; Rigling and Prospero 2018). Transfection of $N$. ditissima with a mycovirus of $C$. parasitica reduced growth of the fungus in vitro (Green 2005). However, in the same study, reductions in virulence of $N$. ditissima were not observed when tested in detached fruit assays. Further work testing the effects of strains infected with mycoviruses on other host tissues with active cankers is needed. Hypoviruses and hypovirulent fungal strains have been reported from apple pathogens including Alternaria alternata hypovirus 1 (AaHV1) isolated from the apple leaf spot pathogen A. alternata f. sp. mali (Li et al. 2019) in China, and Valsa ceratosperma hypovirus 1 (VcHV1) isolated from the apple dieback pathogen $V$. ceratosperma in Japan (Yaegashi et al. 2012). These may have potential as BCAs.

\section{Hygiene and cultural methods}

Pruning out of cankers and prompt removal of heavily infected trees is currently the most effective and widely adopted practice due to a lack of alternative management options (Saville and Olivieri 2019). Growth cracks in trees, particularly where branching occurs, are further sites for pathogen entry (Swinburne 1975). The growth cracks can be exacerbated by high nitrogen and irrigation inputs and subsequent rapid host growth. Growers can reduce this risk by optimising the amount and timing of nitrogen rich fertilisers and irrigation.

The establishment and maintenance of healthy orchards requires disease-free nursery material, and improvements in propagation methods in the nursery can potentially reduce the risk of canker in nursery material (Weber and Børve 2021). The current Knip-boom propagation technique, a Dutch technique used for commercial trees where the central leader is retained with a tier of wide-angled side shoots at 70-100 cm, involves the wounding of trees, and hence sites for pathogen entry (Saville and Olivieri 2019). The use of alternative methods such as producing maiden trees (single stem young trees usually $1-2 \mathrm{~m}$ tall) is being used during the production of particularly canker susceptible varieties as there is less wounding of trees. Cold storage of nursery trees at $2{ }^{\circ} \mathrm{C}$ before planting in new orchards is another management factor that can affect canker. Lifting nursery trees, cold storing over the winter period, and planting in spring can have the effect of increasing canker once trees are planted out in the orchard (Xu 2021). Canker counts were found to be affected by scion variety with Kanzi, Jazz and Rubens having more cankers than Golden Delicious and Grenadier when refrigerated, although how this is affected by time since planting in the orchard is not known.

\section{Disease monitoring and forecasting}

Inspection of trees in orchards for cankers during winter pruning and for shoot dieback in spring and summer will give an indication of canker incidence. Orchards where $25 \%$ or more of the trees have cankers are considered high risk (Berrie 2019). Cankers resulting from infection of leaf scars the previous autumn will not usually become visible until the following spring, from blossom onwards (Berrie 2019). Weather is an important factor for canker, particularly rainfall during key infection periods e.g. late blossom/petal fall for fruit infections, and autumn leaf fall for leaf-scar infection.

Early warning systems for canker include NECTEM contained in Adem ${ }^{\mathrm{TM}}$ (Xu and Butt 1993), and a model developed in Chile (Latorre et al. 2002). The models are driven by weather data including temperature, rainfall, surface wetness duration, and relative humidity.

\section{Apple powdery mildew}

Apple powdery mildew, caused by the fungus Podosphaera leucotricha, is one of the most important diseases of apple in the eastern UK, however less so in the west due to weather conditions being less conducive to the disease (AHDB 2020f). All parts of the tree can be infected including fruit. Powdery mildew reduces fruit yield and quality and repeated infections over subsequent years weaken the tree. Podosphaera leucotricha is an obligate parasite, and overwinters as mycelia in dormant buds infected during the previous growing season. Thus, in northern mainland Europe, the disease is not as serious, as the cold winters $\leq-12^{\circ} \mathrm{C}$ usually kill the overwintering inoculum (AHDB 2020f). Secondary infections occur in the canopy throughout the growing season, depending on weather conditions, and infect leaves, flowers and developing fruit (Amiri and Gañán 2019). 


\section{Biological control agents, nutrients, silicon, elicitors,} biostimulants, and cultural methods

Durable host resistance is recommended as key to powdery mildew management. However, the absence of total immunity in current commercial varieties, and the ongoing risk of $P$. leucotricha overcoming host resistance requires an integrated disease management strategy (Amiri and Gañán 2019; AHDB 2020f). AHDB TF223 (2020) showed alternative management methods used in combination with conventional fungicides AHDB TF223 (2020) gave the same level of mildew management by the end of July (mid-summer in the UK) on the two varieties tested (Gala and Braeburn). The alternative products incorporated into programmes included Mantrac Pro (a manganese-based nutrient (Yara, Grimsby, Lincolnshire, UK), SB Invigorator (various nutrients and plant products providing physical control. SB Products, Vale, Guernsey, UK), Trident (silicon, copper and zinc nutrients potentially producing an elicitor effect, Orion Future Technology Ltd, Colchester, Essex, UK), and Crop Biolife (flavanoids that have elicitor and biostimulant effects, Aussan Laboratories Pty Ltd, Campbellfield, Victoria, Australia). Application of the nutrient based products may boost tree health, with elicitor and/or biostimulant effects. There were no conventional fungicide free treatments so it is difficult to estimate the effects the alternative products on mildew when used on their own.

Pruning and discarding infected shoots showing symptoms of primary mildew in early spring is another option to reduce inoculum load, however this is labour intensive (Holb and Kunz 2016). The removal of alternate hosts from the site, such as rose bushes, has also been suggested as an option to reduce pathogen inoculum load (Amiri and Gañán 2019).

\section{Disease monitoring and forecasting}

Mildew is ubiquitous in apple orchards and routine management is needed from green cluster until vegetative growth ceases (AHDB 2020f). Podem ${ }^{\mathrm{TM}}$ is a PC-based system which provides risk warning for powdery mildew (Xu 1999). The model incorporates weather variables including rainfall, surface wetness duration, ambient temperature and ambient relative humidity. The mildew model forecasts secondary mildew infection by combining effects of weather on spore production and dispersal, and subsequent colony development on young leaves, with varietal susceptibility and mildew inoculum recorded in the orchard (low, moderate or high). Mildew risk is predictive, as it forecasts the amount of sporulating mildew in 3-4 days. The index of mildew risk generated can be used to assist in decision-making and mildew management.

\section{Apple replant disease (ARD)}

ARD occurs when new trees are planted in the same soil where apple trees were previously grown (Mao and Wang 2019; Winkelmann et al. 2019). Symptoms include stunted growth, shortened branch internodes, smaller and lighter green leaves, root tip necrosis, reduced root biomass, reduced yield, reduced fruit size and weight, discolouration of fruit skin, altered fruit aroma and tree death (Xu and Berrie 2018; Mao and Wang 2019). Profitability of an orchard can be reduced by up to $50 \%$ if ARD is present (van Schoor et al. 2009). The recent practice of apple fruit wall production systems planted in to soil previously planted with apple, has resulted in ARD occurring after tree establishment and subsequent reduced financial returns (Xu and Berrie 2018).

It is now generally accepted that ARD is caused by a number of pathogens in a disease complex, with severity influenced by site factors including the environment and soil characteristics (Xu and Berrie 2018; Tilston et al. 2020). Every known biotic factor associated with ARD does not need to be present to cause the disease, and the relative importance of each factor may vary from site to site. Several organisms are implicated in the ARD complex including oomycetes (Phytophthora cactorum, Pythium irregulare), fungi (Thelonectria (formerly Cylindrocarpon) lucidum, Fusarium sp., Ilyonectria sp., Rhizoctonia sp.) and nematodes (Pratylenchus spp.) (Jaffee et al. 1982; Mazzola et al. 2009; Ceustermans et al. 2018; Mao and Wang 2019; Nyoni et al. 2019; Hewavitharana et al. 2020). Reduced abundance of AMF OTUs have been found in soil with ARD affected trees, suggesting a reduced presence of AMF in these soils (Deakin et al. 2019). Microbes that are present in ARD-free soil have also been implicated in the growth of healthy trees. These include Bacillus sp., Streptomyces sp., Pseudomonas sp. and Chaetomium sp. (Nicola et al. 2017). In addition to biotic factors, abiotic factors such as soil fertility, degraded soil structure, residual herbicide activity, and phytotoxicity of plant roots have been linked to the disease (Hewavitharana et al. 2020).

\section{Alternatives to conventional chemicals Planting position}

Soil microbial community structure of apple orchards has been shown to differ between tree stations and inter-row grass aisles, even when locations are just metres from each other (Deakin et al. 2018). Planting new apple trees in the inter-row is seen as one of the simplest non-conventional chemical methods to manage ARD (Rumberger et al. 2004; Kelderer et al. 2012). Inter-row planting avoids areas where risk of infection and infestation by ARD agents is highest. However, if trees are planted in the inter-row area, care needs to be taken to manage 
weeds as competition during the early tree establishment stage may cause more damage than ARD itself (Xu and Berrie 2018).

\section{Crop rotation}

Crop rotation has been used effectively to reduce ARD. Hewavitharana et al. (2020) reported that a five-year or longer crop rotation to a non-woody crop reduced pressure from ARD causing organisms. Pan et al. (2017) found short-term rotation with Allium fistulosum mixed with Trichoderma effective for alleviating ARD, and Mao and Wang (2019) reported a mixed cropping system with spring onions lead to lower populations of diseasecausing fungi such as Fusarium oxysporum. Interestingly, other crops can act as hosts of ARD associated pathogens, hence crop rotation is not always a guaranteed strategy to reduce ARD.

\section{Rootstock selection}

Rootstocks are reported to differ in tolerance to ARD, particularly the GENEVA ${ }^{\circledR}$ series, while the Malling (M) and Malling-Merton (MM) are reported as susceptible (Leinfelder and Merwin 2006). Planting more vigorous scion/rootstock combinations and rootstock genotypes more dissimilar to the one previously planted are recommended on known ARD-affected sites (Xu and Berrie 2018). Deakin et al. (2019) found that replanting trees with a rootstock genotype different from the previous one, can be effective in reducing ARD, and that susceptibility to ARD is likely to be influenced by host genotype. The production of ARD free rootstocks in the propagation phase is important. If ARD agents are present during propagation they may be transported to new sites through the nursery supply chain.

\section{Soil amendments}

Application of amendments such as AMF, PGPR, brassicaceous amendments, biochar, seaweed, and fermented organic materials, have been reported as remedies for ARD. Current research is focusing on identification of biological alternatives to improve the health of soil and in turn aid tree growth and productivity. The application of PGPR to apple trees was shown to increase yield, tree growth, and nutrient content of leaves (Aslantaş et al. 2007; Pirlak et al. 2007), while addition of AMF has been found to increase resistance to Neonectria ditissima (Berdeni et al. 2018). AMF application affects the soil microbiome differently in organic orchards versus orchards where conventional chemicals are applied, with organic orchards having greater richness of AMF compared to orchards using conventional chemicals (Purin et al. 2006). With respect to nematodes, apple seedlings grown with AMF amendments have been reported to be affected less by the presence of Pratylenchus penetrans (lesion nematodes) (Ceustermans et al. 2018).

The use of brassicaceous amendments have shown positive results in organic orchards in reducing effects of ARD. In an experiment in the US state of Washington, brassica seed meals (Brassica juncea: Brassica napus) added in a 1:1 ratio to soil planted with M26 rootstock/ Gala scion trees performed as well in as those cultivated in fumigated soil (Mazzola and Brown 2010). Brassicaceous-based soil amendments used in conjunction with rootstocks have been shown to reduce nematode populations (Mazzola et al. 2009). Wang and Mazzola (2019) found brassica seed meal applications increased tree growth and reduced replant disease relative to trees without the amendment added. They also observed a reduction in replant disease when using rootstocks G.41 and G.210 in addition to the brassica seed-meal soil treatment. However, brassica-based green materials, AMF and PGPR incorporated into soils may only be active against fungal pathogens and not oomycetes (Xu and Berrie 2018).

The use of biochar has mixed results. Wang et al. (2014) reported ARD was reduced through activation of antioxidant enzymes, decreased lipid peroxidation, and reducing phenolic acid content of soil. However, Khorram et al. (2019) found the addition of biochar (and compost) did not increase yield and fruit quality due to a limited ability to suppress ARD. Although there were other benefits such as improved soil quality (nutrient content, decreased bulk density), and increased plant growth. Seaweed-based organic fertilisers have been found to reduce ARD through promoting apple seedling growth and increasing soil enzyme activity (Wang et al. 2016). Fungal community profiles were found to be different when greater amounts of seaweed were added (40 g seaweed per $\mathrm{kg}$ of soil compared to 0,5 , or $20 \mathrm{~g}$ seaweed per $\mathrm{kg}$ of soil) (Wang et al. 2016). The addition of fermented organic materials has been reported to reduce ARD. Zhang et al. (2012) tested two fermentation methods to produce organic material, one aerobic generating solid compost and the other anaerobic generating fermented liquid. In a pot experiment using apple seedlings planted in new cropping soil, ARD soil, ARD soil + solid compost added, and ARD soil + fermented fluid added, the ARD + fermented liquid was found to be superior to $\mathrm{ARD}+$ solid compost for reducing ARD. The ARD + fermented liquid had a higher bacterial content compared to the ARD + solid compost, and the new cropping soil.

Anaerobic soil disinfestation (ASD) is a variation on organic amendment addition, where granular or liquid plant extracts are added to the ARD affected soil, and covered with a plastic sheet for 3-4 weeks (Xu and Berrie 2018). The temperature of the soil subsequently increases, 
and the abundance of beneficial bacteria increases. Herbie $82^{\circledR}$ (Thatchtec BV, Wageningen, The Netherlands) is a product used for ASD and has been shown to increase vigour of plants grown in ARD affected soil when that soil is covered with a film for 3-4 weeks (Mancini et al. 2014). However, the use of ASD products in the UK would likely need Chemical Regulation Division (CRD) approval before commercial use.

\section{Soil water management}

Soil water management including improving water infiltration into soil, reducing compaction and improving soil structure through addition of organic matter has also been recommended to treat ARD. Limiting periods of soil saturation and selecting sites with good drainage is essential (Hewavitharana et al. 2020). Oomycetes in the ARD complex can disperse between trees if the soil is saturated. Saturated soil also aids in dispersal and subsequent infection of roots by oomycetes. Reducing periods of soil saturation will reduce oomycete populations and dispersal and subsequent disease problems.

\section{Brown rot and blossom wilt}

Brown rot is one of the most important causes of rot of stored apples, and also leads to significant losses in the orchard pre-harvest. In the UK, brown rot of apple is caused by Monilinia fructigena and M. laxa (Table 1). There are brown rot quarantine pathogens not currently present in the UK including Monilinia fructicola and Monilinia polystroma. Both M. fructicola and M. polystroma have been detected in mainland European countries, and thus there is a high risk of introduction in to the UK (Holb 2019; CABI 2020).

Pre-harvest losses to brown rot in organic pome-fruit orchards of up to $45 \%$ have been reported, while yield loss in unsprayed orchards can range from 50 to $90 \%$ (Holb 2007, 2019; Berrie and Holb 2014). Post-harvest losses, particularly due to $M$. fructigena can as high as $22 \%$ (Berrie and Holb 2014; Holb 2019). In the UK, brown rot of apple fruit by $M$. fructigena is mainly dependant on the presence of wounds caused by biotic and abiotic wounding agents. In contrast, M. laxa can infect both healthy and wounded fruit. The incidence of brown rot in organic orchards is significantly higher due to greater chance of pest injury (Holb and Scherm 2007). Late ripening varieties show more severe brown rot than earlier ripening varieties (Holb and Scherm 2007, 2008).

\section{Alternatives to conventional fungicides Cultural methods}

Sanitary measures and hygiene are effective at reducing or eliminating sources of Monilinia inoculum. Primary infections occur from overwintered infected blossoms, twigs, fruit, spurs and branches (Holb 2019). Infected material should be removed whenever signs of the disease occur. Insect management is also key as the wounding they cause can create pathogen entry sites. AHDB (2020c) recommends cultural management including pruning of cankers in winter; removing mummies during pruning and those under the tree; remove infected fruit as soon as the disease symptoms appear; remove waste fruit from early pollinator varieties so they are not a source of inoculum for the main orchard variety (mummies and diseased fresh fruit should be throw into the grass alley where they can be macerated by mowing); use early varieties as pollinators; at harvest, selectively pick fruit so only healthy appearing fruit is placed in the bin to reduce incidence of brown rot in storage; and avoid damage to fruit, especially at harvest.

\section{Host resistance}

Host resistance varies between varieties, with physiological characters including thicker fruit skin, low cracking susceptibility, higher acidity and higher phenolic content correlated with reduced disease. However many of these characters are also associated with poor marketing quality (Byrde and Willets 1977; Holb 2004). Brown rot is also dependant on the stage of fruit maturity, with mature fruit being more susceptible than immature fruit (van Leeuwen et al. 2000; Xu and Robinson 2000; Holb 2019).

\section{Biological control agents}

The apple fruit surface has been reported to be an excellent source of naturally occurring antagonists against postharvest fruit decay (Janisiewicz and Korsten 2002). Both endophytic and epiphytic fungi have been reported as having inhibitory effects on Monilinia spp. of apple. The endophytic yeasts Schwanniomyces vanrijiae, Galactomyces geotrichum, Pichia kudriavzevii, Debaryomyces hansenii, and Rhodotorula glutinis were found to inhibit $M$. fructigena when inoculated on apple fruit as well as in vitro (Madbouly et al. 2020). The epiphytic fungi Aureobasidium pullulans, Epicoccum purpurascens, Sordaria fimicola, and Trichoderma polysporum isolated from apple leaves and applied individually or in mixtures

Table 1 Species of Monilinia causing rot, canker, and wilt diseases of apple in the UK (AHDB 2020c, d; Holb 2019)

\begin{tabular}{lll}
\hline Host & M. fructigena & M. laxa \\
\hline Apple & Fruit rot (common and destructive); black apple; canker & Blossom wilt (M. laxa f.sp. mali); canker; black apple (rare); fruit rot (rare) \\
\hline
\end{tabular}


to wounded apples, were also found to give good protection against M. fructigena (Falconi and Mendgen 1994).

\section{Physical management}

Several methods of physical management are used to reduce disease caused by Monilinia spp. particularly post-harvest. These include controlled atmosphere (CA) storage, hydro-cooling, hydrair-cooling, heat, hot water brushing, UV-light and other forms of radiation (Holb 2019). CA conditions will not prevent infection of fruit in store although the composition of the atmosphere can influence the degree of rotting (AHDB 2020e). Ultra-low oxygen conditions below $1 \%$ have been shown to almost eliminate brown rot of apple caused by $M$. fructigena, compared to $18-35 \%$ oxygen used in conventional storage (Holb et al. 2012). With the apple variety Cox, CA conditions that are low in oxygen and high in carbon dioxide are more conducive to rotting than low oxygen only (AHDB 2020e). Cox apples in medium or long-term storage should be kept in low oxygen and low carbon dioxide conditions particularly where there is a history of brown rot.

After harvest fruit is usually hydro-cooled to $0-3{ }^{\circ} \mathrm{C}$, however the cooling water can harbour pathogen propagules (Holb 2019). Hydrair-cooling is another cooling method where cold air is used instead of water, and reduces the risk of pathogen transmission. Post-harvest hot-water treatment of fruit may be used to reduce storage rots. The method is reported to work through a heat shock-induced antimicrobial response rather than a direct killing of fungal inoculum. Maxin et al. (2014) found hot-water treatment of freshly harvested apple fruit for 3 min at $50-52{ }^{\circ} \mathrm{C}$ was efficacious against most storage rots including Monilinia spp.. Shorter exposures for $<30 \mathrm{~s}$ at $55-60{ }^{\circ} \mathrm{C}$ also provided good control. In an earlier study by Maxin et al. (2012), significant reductions in the incidence of fruit rot caused by $M$. fructigena was achieved by incubation periods of $3 \mathrm{~min}$ at 50 to $54{ }^{\circ} \mathrm{C}$ (dipping) and 20 or $25 \mathrm{~s}$ at $55^{\circ} \mathrm{C}$ (rinsing), followed by up to 100 days cold-storage at $2{ }^{\circ} \mathrm{C}$ and 14 days at $18{ }^{\circ} \mathrm{C}$.

Radiation is a more recent method used for brown rot management. When applied post-harvest, the method heats and disinfects the fruit. Low hormetic doses of ultraviolet light (254 $\mathrm{nm}, \mathrm{UV}-\mathrm{C})$ are reported to reduce postharvest decay of Golden Delicious apples caused by Monilina spp. (Stevens et al. 1996), while gamma irradiation has also been reported to reduce fungal development and rot of apple caused by M. fructigena (Marcaki 1998).

\section{Disease forecasting}

A disease warning system for $M$. fructigena in organic apple production has been developed (Holb 2009; Holb et al. 2011). The brown rot forecasting and management strategy (BRFMS) is coupled with both disease and insect components. Holb et al. (2011) states that the model contains four parts: "(1) data insertion and analyses by computer simulation of pathogen sub-models, (2) calculation of yield loss threshold levels based on disease incidence, (3) determination of epidemic intensity levels, (4) a decision module with suggestions for disease management practices for each epidemic intensity level". Use of the BRFMS resulted in a $22-33 \%$ reduction in the number of sprays compared to the regular brown rot spray schedule.

\section{The threat of invasive apple pathogens not currently in the UK}

Xylella fastidiosa is the most serious exotic pathogen threat to UK horticulture, has been reported to infect apple, and was recently reported on apple in France (Mehta and Rosato 2001; Jeger et al. 2018). The pathogen is a xylem limited fastidious bacterium, and infection can be asymptomatic (Baldi and La Porta 2017) making detection challenging. Taxonomically, $X$. fastidiosa is composed of six subspecies (Denancé et al. 2019). Since 2013, various cases have been reported in Europe (Italy, France, Germany and Spain) a wide range of host plants including pear, olive, grape and ornamentals (Mehta and Rosato 2001; Su et al. 2014; European and Mediterranean Plant Protection Organization 2020). The detection of $X$. fastidiosa in Puglia, southern Italy, represented the first confirmed detection in Europe. The introduction pathways of $X$. fastidiosa into Asia or Europe are unclear. However, EPPO member countries e.g. France, the Netherlands, and Switzerland have intercepted X. fastidiosa several times on ornamental coffee plants imported from South America (European and Mediterranean Plant Protection Organization 2020).

Xylella fastidiosa generally causes disease in warmer climates. The Department of Environment, Food and Rural Affairs (2020b) reports that of the known European outbreaks, $X$. fastidiosa subspecies multiplex is of most concern to the UK and was detected in Corsica, mainland France, mainland Spain and Portugal, and in a small area of southern most Tuscany, and in nursery stock on the Spanish Balearic Islands. Xylella fastidiosa subspecies multiplex is able to survive in cooler climates and affect a wide range of hosts, including many native broadleaved trees such as oak. The current epidemic in Europe has occurred primarily in warmer regions. The greatest risk of introduction to the UK is via infected plants imported through the horticultural trade. Once established, the pathogen is transmitted by sucking insects including spittlebugs, leaf hoppers, sharp shooters, frog hoppers and cicadas (Jeger et al. 2018). The widespread meadow spittlebug for example, 
is responsible for transmitting the disease in Italy (Cornara et al. 2017; Santoiemma et al. 2019).

Valsa spp. are pathogens of apple occurring in various locations including sub-Saharan Africa and East Asia (China, Japan and Korea) (CABI 2014; Li 2019). In China, there have been four epidemics of disease caused by Valsa spp. since the 1940s with almost all of the apple orchards destroyed in the 1980s (Li 2019). In 2008, disease incidence was as high as $85 \%$ in some regions (Cao et al. 2009). The species of Valsa isolated from apple in China have been identified using molecular and morphological data as Valsa mali and Valsa malicola. Valsa mali was reported to cause $90 \%$ of apple canker in China, while $V$. malicola was found to be a weak pathogen of apple. It is currently unknown what impact the Asian species of Valsa would have on apple in the UK, particularly under a warming climate.

\section{Effects of climate change}

Since the industrial revolution and particularly since the 1980s there has been an overall increase in global average temperature including in the UK (Met Office 2020a). The summer of 2018 in the UK had monthly mean temperatures $1.8^{\circ} \mathrm{C}$ above the 1981 to 2010 average in June, $2.2{ }^{\circ} \mathrm{C}$ above the average in July, and $0.3{ }^{\circ} \mathrm{C}$ above the average in August (Met Office 2020b). The increases in temperature are closer to the optimum temperatures for various bacterial pathogens including E. amylovora and X. fastidiosa and increases the probability of infection and survival, in the case of $X$. fastidiosa, establishment in the UK after introduction.

Climate change will likely impact a range of pathogens that would normally not be able to survive UK winters or exist at lower incidence and severity due to the cooler UK climate. A key example is fireblight caused by E. amylovora. Currently, fireblight is of only sporadic concern in the UK, and mainly affects pear. Fireblight risk is greatest when temperatures exceed $18{ }^{\circ} \mathrm{C}$ and there is sufficient rain. Disease development occurs between 5 and $30{ }^{\circ} \mathrm{C}$ with an optimum temperature of $27{ }^{\circ} \mathrm{C}$ (AHDB 2020g). In vitro and in planta studies by Feil and Purcell (2001) showed temperatures between 25 and $32{ }^{\circ} \mathrm{C}$ are critical to the lifecycle of $X$. fastidiosa because of its rapid growth rate at these temperatures, whereas temperatures below $12-17{ }^{\circ} \mathrm{C}$ and above $34{ }^{\circ} \mathrm{C}$ may reduce the survival of the pathogen in plants. The range and severity of $X$. fastidiosa also depends on the distribution of insect vectors whose biology and reproduction are influenced by temperature.

Climate change may also affect the physiology and epidemiology of established diseases of apple in the UK. In an apple orchard, Bannon et al. (2009) observed an increase of airborne $M$. fructigena conidia counts associated with higher temperatures, which was related to the development of the fungus. With apple powdery mildew, warmer winters will result in greater survival of overwintered primary inoculum and allow more infections to occur the following year (AHDB 2020f). The fungal family Botryosphaeriaceae are geographically and ecologically cosmopolitan and contain many plant pathogens including those that cause canker and fruit rot of apple (Bertetti et al. 2012; Phillips et al. 2013; CABI 2019a, b). The Botryosphaeriaceae cause disease mainly in warmer climates, and higher temperatures in the UK will likely favour infections. Higher temperatures and more extreme weather also impact tree health, increasing stress and susceptibility to pathogens.

Increasing temperatures affect the number of chilling hours that temperate trees are exposed to, which impacts flowering and fruit set (Ramírez and Kallarackal 2015). Warmer winters also lead to trees flowering earlier and over an extended period of time, leading to increased risk of frost damage (Pfleiderer et al. 2019). The exact consequences of climate change are difficult to predict due to the changeable nature of the weather and the variation in factors contributing to climate change. However, a warming planet favours range expansion of many pests and pathogens, while simultaneously increasing plant stress and susceptibility.

\section{Further areas of research}

The use of robotics for the application of UV-C radiation to reduce powdery mildew is a key area of current research. Robots have mainly been applied to strawberry and grape production for disease management (Saga Robotics 2020; APS 2020; Interreg 2021). However, there is scope for development of robots for operation in apple orchards, particularly those that have trellised trees and are grown on dwarfing rootstocks. How UV-C radiation will be legislated in organic apple production in the UK is currently under review.

Another area of further research is optimising the method, dose, and timing of each organic method/s to each disease. Individual BCAs and biostimulants in powdery mildew management of strawberry in the UK have been found to provide effective disease reduction (Berrie and $\mathrm{Xu}$ 2021). In addition, variety selection, crop husbandry (canopy management, ventilation), disease risk modelling and forecasting, regular UV application by robots, and consistent visual disease monitoring throughout the season would likely provide further disease protection. The phenological stage of the tree (stages of bud burst, developing leaves, flower buds and mature flowers, immature and mature fruit) are also considerations when 
determining the optimum application time and dose for BCAs.

\section{Conclusion}

Organic farming and non-chemical management methods are becoming more important to the sustainability of UK apple production, and globally for horticulture in general. Regulatory agencies continue to ban or restrict the use of conventional chemicals. This is in concert with consumer demands for safer food products free from harmful pesticides, and management options with lower environmental impact. These changes are often challenging for growers, who have relied on the more predictable and reliable disease control afforded by conventional chemicals. However, organic disease management is generally more sustainable long term as they often have fewer negative impacts on the environment and human health. This review has presented innovative research and results that continue to be avenues of research, and some of which can already be applied as alternatives to conventional pesticides to provide economic efficiency, environmental sustainability, and the supply of safe nutritious food.

\section{Acknowledgements \\ I acknowledge Dr Michelle Fountain and Dr Bethan Shaw for assistance with sourcing funding, Prof. Xiangming $\mathrm{Xu}$, and three anonymous reviewers for providing useful comments and corrections.}

\section{Authors' contributions}

LAS researched and wrote the article, is the corresponding author, and was the primary contact during the publication process. The author read and approved the final manuscript.

\section{Funding}

This work was funded by the Agriculture and Horticulture Development Board (AHDB), UK.

\section{Availability of data and materials}

Not applicable.

\section{Declarations}

Ethics approval and consent to participate Not applicable.

\section{Consent for publication}

Not applicable.

\section{Competing interests}

The author declares that there is no commercial or financial conflicts of interest.

Received: 12 December 2020 Accepted: 12 August 2021

Published online: 07 September 2021

\section{References}

Aćimović SG, Rosenberger DA. An introduction to the RIMpro apple scab prediction model. Scaffolds Fruit J. 2018;27:1-5.
AHDB TF223. Improving integrated pest and disease management in tree fruit. Agriculture and Horticulture Development Board; 2020. https:// ahdb.org.uk/tf-223-improving-integrated-pest-and-disease-manag ement-in-tree-fruit.

Alston F. Response of apple cultivars to canker, Nectria galligena. Annu Rep East Malling Res Stn. 1969;1969(A53):147-8.

Amiri A, Gañán L. Chapter 2. Powdery mildew: biology, epidemiology, and management of Podosphaera spp. of tree fruit. In: Integrated management of diseases and insect pests of tree fruit. Burleigh Dodds; 2019. p. 21-38.

Andrews JH. Microbial antagonism to the imperfect stage of the apple scab pathogen, Venturia inaequalis. Phytopathology. 1983;73(2):228.

AHDB. Apple Best Practice Guide; Apple scab-additional information. Agriculture and Horticulture Development Board; 2020a. https://apples. ahdb.org.uk/apple-scab-additional-information.asp\#link2.

AHDB. Apple Best Practice Guide; Apple canker (Neonectria ditissima). Agriculture and Horticulture Development Board; 2020b. https://apples. ahdb.org.uk/apple-canker.asp.

AHDB. Apple Best Practice Guide; Brown rot-additional information. Agriculture and Horticulture Development Board; 2020c. https://apples. ahdb.org.uk/brown-rot-additional.asp.

AHDB. Apple Best Practice Guide; Blossom wilt (Monilinia laxa f.sp. mali). Agriculture and Horticulture Development Board; 2020d. https:// ahdbapples.azurewebsites.net/blossom-wilt.asp.

AHDB. Apple Best Practice Guide; Optimal storage conditions. Agriculture and Horticulture Development Board; 2020e. https://apples.ahdb. org.uk/post-harvest-section9.asp.

AHDB. Apple Best Practice Guide; Apple powdery mildew-additional information. Agriculture and Horticulture Development Board; 2020 f. https://apples.ahdb.org.uk/apple-powdery-mildew-additional-infor mation.asp.

AHDB. Apple Best Practice Guide; Fireblight (Erwinia amylovora). Agriculture and Horticulture Development Board; 2020g. https://apples.ahdb. org.uk/fireblight.asp

APS. Robotics Revolution. Plantopia podcast. The American Phytopathological Society; 2020. https://www.plantopiapodcast.org.

Aslantaş R, Çakmakçı R, Sahin F. Effect of plant growth promoting rhizobacteria on young apple tree growth and fruit yield under orchard conditions. Sci Hortic. 2007;111:371-7.

Bacon CW. Abiotic stress tolerances (moisture, nutrients) and photosynthesis in endophyte-infected tall fescue. Agric Ecosyst Environ. 1993;44(1):123-41.

Baldi P, La Porta N. Xylella fastidiosa: host range and advance in molecular identification techniques. Front Plant Sci. 2017;8.

Bálint J, Szilveszter N, Thiesz R, István N, Adalbert B. Using plant extracts to reduce asexual reproduction of apple scab (Venturia inaequalis). Turk J Agric for. 2014;38:91-8.

Bannon F, Gort G, van Leeuwen G, Holb I, Jeger M. Diurnal patterns in dispersal of Monilinia fructigena conidia in an apple orchard in relation to weather factors. Agric for Meteorol. 2009;149(3):518-25.

Bazzi C, Messina C, Tortoreto L, Stefani E, Bini F, Brunelli A, et al. Control of pathogen incidence in pome fruits and other horticultural crop plants with prohexadione-Ca. Eur J Hortic Sci. 2003;68:108-14.

Becker C, Burr T, Smith C. Overwintering of conidia of Venturia inaequalis in apple buds in New York orchards. Plant Dis. 1992;76(2):121-6.

Berdeni D, Cotton TEA, Daniell TJ, Bidartondo MI, Cameron DD, Evans KL. The effects of arbuscular mycorrhizal fungal colonisation on nutrient status, growth, productivity, and canker resistance of apple (Malus pumila). Front Microbiol. 2018;9:1461.

Berrie A, Xu X. Managing apple scab and powdery mildew using Adem ${ }^{\text {TM }}$. Int J Pest Manag. 2003;49:243-50.

Berrie A. Chapter 9. Disease monitoring and decision making in integrated fruit disease management. In: Integrated management of diseases and insect pests of tree fruit. Burleigh Dodds; 2019. p. 201-32.

Berrie A, Holb I. Brown rot diseases. In: Sutton, Aldwinckle, Agnello, Walgenbach, editors. Compendium of apple and pear diseases and pests. 2nd edn. St Paul, MN: American Phytopathological Society; 2014. p. $43-45$.

Berrie A, Xu X. Developing biopesticide-based programmes for managing powdery mildew in protected strawberries in the UK. Crop Prot. 2021;149:105766. 
Bertetti D, Poli A, Gullino M, Garibaldi A. First report of fruit rot caused by Botryosphaeria dothidea on European pear (Pyrus communis) cultivated in Italy. Prot Delle Colt. 2012;4:60-4.

Bini F, Ragaini A, Bazzi C. Resistance responses induced by the plant growth retardant prohexadione-Ca in apple against scab infections. Ann Appl Biol. 2008;152(1):19-27.

Bousset L, Blaise P, Kellerhalls M, Gessler C. Mixtures of apple cultivars in orchards: effect on the scab epidemics. IOBC WPRS Bull 1997;42-48.

Bulgarelli D, Schlaeppi K, Spaepen S, van Themaat EVL, Schulze-Lefert P. Structure and functions of the bacterial microbiota of plants. Annu Rev Plant Biol. 2013;64(1):807-38.

Burchill RT, Hutton KE, Crosse JE, Garrett CME. Inhibition of the perfect stage of Venturia inaequalis by urea. Nature. 1965:205(4970):520-1

Burr TJ, Matteson MC, Smith CA, Corral-Garcia MR, Huang T-C. Effectiveness of bacteria and yeasts from apple orchards as biological control agents of apple scab. Biol Control. 1996;6(2):151-7.

Busby PE, Ridout M, Newcombe G. Fungal endophytes: modifiers of plant disease. Plant Mol Biol. 2016:90(6):645-55.

Byrde RJW, Willets HJ. The brown rot fungi: their biology and control. Oxford: Pergamon Press; 1977

CABI. Valsa mali, dieback of apple [pest/pathogen]. In: Crop Protection Compendium UK, CAB International; 2014. p. Sheet 3839. https://www.cabdi rect.org/cabdirect/abstract/20097403839.

CABI. Invasive Species Compendium; Datasheet; Additional resources; Botryosphaeria ribis (canker: apple). UK, CAB International; 2019a. https:// www.cabi.org/isc/datasheet/9633.

CABI. Invasive Species Compendium; Datasheet; Additional resources; Botryosphaeria dothidea UK, CAB International; 2019b. https://www.cabi.org/ isc/datasheet/9627.

CABI. Invasive Species Compendium; Datasheet; Additional resources; Monilinia fructicola (brown rot) CAB International; 2020. https://www.cabi. org/isc/datasheet/34746.

Cao K, Guo L, Li B, Sun G, Chen H. Investigations on the occurrence and control of apple canker in China. Plant Prot. 2009;35:114-6.

Ceustermans A, Van Hemelrijck W, Van Campenhout J, Bylemans D. Effect of arbuscular mycorrhizal fungi on Pratylenchus penetrans infestation in apple seedlings under greenhouse conditions. Pathogens. 2018;7(4):76.

Cornara D, Saponari M, Zeilinger AR, de Stradis A, Boscia D, Loconsole G, et al. Spittlebugs as vectors of Xylella fastidiosa in olive orchards in Italy. J Pest Sci. 2017;90(2):521-30

Cullen D, Berbee FM, Andrews JH. Chaetomium globosum antagonizes the apple scab pathogen, Venturia inaequalis, under field conditions. Can J Bot. 1984;62(9).

Deakin G, Tilston EL, Bennett J, Passey T, Harrison N, Fernández-Fernández F, et al. Spatial structuring of soil microbial communities in commercial apple orchards. Appl Soil Ecol. 2018;130:1-12.

Deakin G, Fernández-Fernández F, Bennett J, Passey T, Harrison N, Tilston EL, et al. The effect of rotating apple rootstock genotypes on apple replant disease and rhizosphere microbiome. Phytobiomes J. 2019;3(4):273-85.

Denancé N, Briand M, Gaborieau R, Gaillard S, Jacques M-A. Identification of genetic relationships and subspecies signatures in Xylella fastidiosa. BMC Genomics. 2019;20(1):239.

Department of Environment, Food \& Rural Affairs. Agriculture in the United Kingdom 2019 2020a p. 1-157. https://assets.publishing.service.gov.uk/ government/uploads/system/uploads/attachment_data/file/950618/ AUK-2019-07jan21.pdf.

Department of Environment, Food \& Rural Affairs. Plant Health Portal; Xylella fastidiosa 2020b. https://planthealthportal.defra.gov.uk/pests-and-disea ses/high-profile-pests-and-diseases/xylella/.

Didelot F, Brun L, Parisi L. Effects of cultivar mixtures on scab control in apple orchards. Plant Pathol. 2007;56(6):1014-22.

European Commission. Organics at a glance. European Union; 2020. https:/lec. europa.eu/info/food-farming-fisheries/farming/organic-farming/organ ics-glance_en.

European and Mediterranean Plant Protection Organization (EPPO). Xylella fastidiosa in the EPPO region. Special Alert European and Mediterranean Plant Protection Organisation; 2020. https://www.eppo.int/ACTIVITIES/ plant_quarantine/shortnotes_qps/shortnotes_xylella.

Falconi CJ, Mendgen K. Epiphytic fungi on apple leaves and their value for control of the postharvest pathogens Botrytis cinerea, Monilinia fructigena and Penicillium expansum. Z Für Pflanzenkrankh Pflanzenschutz. 1994;101(1):38-47.

Feil $\mathrm{H}$, Purcell AH. Temperature-dependent growth and survival of Xylella fastidiosa in vitro and in potted grapevines. Plant Dis. 2001;85(12):1230-4.

Ghasemkhani M, Garkava-Gustavsson L, Liljeroth E, Nybom H. Assessment of diversity and genetic relationships of Neonectria ditissima: the causal agent of fruit tree canker. Hereditas. 2016;153(1):7.

Gokhale M, Gupta D, Gupta U, Faraz R, Sandhu SS. Patents on endophytic fungi. Recent Pat Biotechnol. 2017;11(2):120-40.

Gómez-Cortecero A, Saville RJ, Scheper RWA, Bowen JK, Agripino De Medeiros $\mathrm{H}$, Kingsnorth J, et al. Variation in host and pathogen in the Neonectria/ Malus interaction; toward an understanding of the genetic basis of resistance to European canker. Front Plant Sci. 2016;7:1365.

Green C. Hypovirus infection of Neonectria galligena and its potential as a biological control agent for apple canker. Imperial College, University of London; 2005. https://ethos.bl.uk/OrderDetails.do?uin=uk.bl.ethos. 414387 .

Harrison R. The nature of resistance to Neonectria ditissima in apple species. UK Research \& Innovation, BB/P000851/1 2021. https://gtr.ukri.org/proje cts?ref=BB\%2FP000851\%2F1.

Hewavitharana S, DuPont T, Mazzola M. Apple replant disease; WSU tree fruit IPM strategies Washington State University; 2020. http://treefruit.wsu. edu/crop-protection/disease-management/apple-replant-disease/.

Holb IJ. The brown rot fungi of fruit crops (Monilinia spp.): II. Important features of their epidemiology. Int J Hortic Sci. 2004;10(1):17-33.

Holb IJ. Effect of pruning on apple scab in organic apple production. Plant Dis. 2005:89(6):611-8

Holb IJ. Monitoring conidial density of Monilinia fructigena in the air in relation to brown rot development in integrated and organic apple orchards. Eur J Plant Pathol. 2007;120(4):397.

Holb IJ. Timing of first and final sprays against apple scab combined with leaf removal and pruning in organic apple production. Crop Prot. 2008;27(3):814-22.

Holb IJ. Fungal disease management in environmentally friendly apple production. In: Climate change, intercropping, pest control and beneficial microorganisms: sustainable agriculture reviews 2. Springer Science+Business Media; 2009. p. 219-293.

Holb I. Chapter 6: Brown rot: causes, detection and control of Monilinia spp. affecting tree fruit. In: Integrated management of diseases and insect pests of tree fruit. Burleigh Dodds; 2019. p. 103-49.

Holb IJ, Kunz S. Integrated control of apple scab and powdery mildew in an organic apple orchard by combining potassium carbonates with wettable sulfur, pruning, and cultivar susceptibility. Plant Dis. 2016;100(9):1894-905.

Holb IJ, Scherm H. Temporal dynamics of brown rot in different apple management systems and importance of dropped fruit for disease development. Phytopathology. 2007;97(9):1104-11.

Holb IJ, Scherm H. Quantitative relationships between different injury factors and development of brown rot caused by Monilinia fructigena in integrated and organic apple orchards. Phytopathology. 2008;98(1):79-86.

Holb IJ, Heijne B, Jeger MJ. Overwintering of conidia of Venturia inaequalis and the contribution to early epidemics of apple scab. Plant Dis. 2004:88(7):751-7.

Holb IJ, Balla B, Abonyi F, Fazekas M, Lakatos P, Gáll JM. Development and evaluation of a model for management of brown rot in organic apple orchards. Eur J Plant Pathol. 2011;129(3):469-83.

Holb IJ, Balla B, Vámos A, Gáll JM. Influence of preharvest calcium applications, fruit injury, and storage atmospheres on postharvest brown rot of apple. Postharvest Biol Technol. 2012;67:29-36.

Interreg. UV-ROBOT-Innovative UV-robotics to improve existing IPM strategies and to benefit farmers, consumers and the environment. Interreg North West Europe; 2021. https://www.nweurope.eu/projects/project-search/ uv-robot-innovative-uv-robotics-to-improve-existing-ipm-strategies/.

Jaffee B, Abawi G, Mai W. Fungi associated with roots of apple seedlings grown in soil from an apple replant site. Plant Dis. 1982;66(1):942-4.

Jamar L. Innovative strategies for the control of apple scab [Venturia inaequalis (Cke.) Wint.] in organic apple production [Gembloux, Belgium]: Université de Liège; 2011. https://orbi.uliege.be/handle/2268/87016.

Jamar L, Lefrancq B, Fassotte C, Lateur M. A during-infection spray strategy using sulphur compounds, copper, silicon and a new formulation 
of potassium bicarbonate for primary scab control in organic apple production. Eur J Plant Pathol. 2008;122(4):481-93.

Janisiewicz WJ, Korsten L. Biological control of postharvest diseases of fruits. Annu Rev Phytopathol. 2002:40(1):411-41.

Jeger M, Caffier D, Candresse T, Chatzivassiliou E, Dehnen-Schmutz K, Gilioli $\mathrm{G}$, et al. Updated pest categorisation of Xylella fastidiosa. EFSA J. 2018;16(7):e05357.

Kelderer M, Manici L, Caputo F, Thalheimer M. Planting in the "inter-row" to overcome replant disease in apple orchards: a study on the effectiveness of the practice based on microbial indicators. Plant Soil. 2012;357:381-93.

Khorram MS, Zhang G, Fatemi A, Kiefer R, Maddah K, Baqar M, et al. Impact of biochar and compost amendment on soil quality, growth and yield of a replanted apple orchard in a 4-year field study. J Sci Food Agric. 2019;99(4):1862-9.

Köhl JJ, Molhoek WWML, Groenenboom-de Haas BBH, Goossen-van de Geijn HHM. Selection and orchard testing of antagonists suppressing conidial production by the apple scab pathogen Venturia inaequalis. Eur J Plant Pathol. 2009;123(4):401-14.

Köhl J, Scheer C, Imre H, Masny S, Molhoek W. Toward an integrated use of biological control by Cladosporium cladosporioides H39 in apple scab (Venturia inaequalis) management. Plant Dis. 2015;1 (99):535-43.

Latorre BA, Rioja ME, Lillo C, Muñoz M. The effect of temperature and wetness duration on infection and a warning system for European canker (Nectria galligena) of apple in Chile. Crop Prot. 2002;21 (4):285-91.

Leinfelder M, Merwin I. Rootstock selection, preplant soil treatments, and tree planting positions as factors in managing apple replant disease. HortScience Publ Am Soc Hortic Sci. 2006;41 (2):394-401.

Li B. Chapter 5. Fungal diseases of fruit: apple canker in Asia. In: Integrated management of diseases and insect pests of tree fruit. Burleigh Dodds; 2019. p. 85-102.

Li H, Bian R, Liu Q, Yang L, Pang T, Salaipeth L, et al. Identification of a novel hypovirulence-inducing hypovirus from Alternaria alternata. Front Microbiol. 2019;10:1076.

MacHardy W. Apple scab: Biology, epidemiology, and management. American Phytopathological Society, St Paul, MN, USA; 1996 (CAB Direct).

Madbouly AK, Elyousr KAMA, Ismail IM. Biocontrol of Monilinia fructigena, causal agent of brown rot of apple fruit, by using endophytic yeasts. Biol Control. 2020;144:104239.

Mancini MM, Kelderer M, Naef A, Rühmer T, Canet R, Franke-Whittle I, et al. BIO-INCROP: Innovative cropping techniques to increase soil health in organic fruit tree crops CORE Organic Il; 2014 p. 1-35.

Mao Z, Wang Y. Chapter 3. Apple replant disease: causes and management. In: Integrated management of diseases and insect pests of tree fruit. Burleigh Dodds; 2019. p. 39-49.

Marcaki P. Investigation of the radiation effects on brown rot disease of Golden Delicious apples, inoculated with the fungus Monilinia fructigena. Mycopathologia. 1998;142(1):33-6.

Maxin P, Weber RWS, Pedersen HL, Williams M. Control of a wide range of storage rots in naturally infected apples by hot-water dipping and rinsing. Postharvest Biol Technol. 2012;70:25-31.

Maxin P, Williams M, Weber RWS. Control of fungal storage rots of apples by hot-water treatments: a northern European perspective. ErwerbsObstbau. 2014;56(1):25-34.

Mazzola M, Brown J. Efficacy of brassicaceous seed meal formulations for the control of apple replant disease in conventional and organic production systems. Plant Dis. 2010;94(7):835-42.

Mazzola M, Brown J, Zhao X, Izzo AD, Fazio G. Interaction of brassicaceous seed meal and apple rootstock on recovery of Pythium spp. and Pratylenchus penetrans from roots grown in replant soils. Plant Dis. 2009;93(1):51-7.

Mehta A, Rosato YB. Phylogenetic relationships of Xylella fastidiosa strains from different hosts, based on 16S rDNA and 16S-23S intergenic spacer sequences. Int J Syst Evol Microbiol. 2001;51(2):311-8.

Met Office. Effects of climate change. 2020a. https://www.metoffice.gov.uk/ weather/climate-change/effects-of-climate-change.

Met Office. UK past events; summaries; Summer 2018. 2020b. https://www. metoffice.gov.uk/binaries/content/assets/metofficegovuk/pdf/weath er/learn-about/uk-past-events/summaries/uk_monthly_climate_ summary_summer_2018.pdf.
Milgroom MG, Cortesi P. Biological control of chestnut blight with hypovirulence: a critical analysis. Annu Rev Phytopathol. 2004;42(1):311-38.

Mills WD, LaPlante AA. Apple scab. Diseases and insects in the orchard. 1951; p. 20-100. Report No.: 711.

Nicola L, Turco E, Albanese D, Donati C, Thalheimer M, Pindo M, et al. Fumigation with dazomet modifies soil microbiota in apple orchards affected by replant disease. Appl Soil ECol. 2017;1(113):71-9.

Nyoni M, Mazzola M, Wessels JPB, McLeod A. The efficacy of semiselective chemicals and Chloropicrin/1,3-Dichloropropene-containing fumigants in managing apple replant disease in South Africa. Plant Dis. 2019;103(6):1363-73.

Olivieri L. European apple canker (Neonectria ditissima): asymptomatic colonisation of internal plant tissues and endophyte diversity in scion cultivars differing in disease susceptibility [PhD Thesis]. Royal Holloway University of London; 2021.

Pan F, Xiang L, Wang S, Li J, Shen X, Chen X, et al. Effects of short-term rotation and Trichoderma application on the soil environment and physiological characteristics of Malus hupehensis Rehd. seedlings under replant conditions. Acta Ecol Sin. 2017;37(5):315-21.

Parisi L, Lespinasse Y, Guillaumes J, Kruger J. A new race of Venturia inaequalis virulent to apples with resistance due to the Vf gene. Phytopathology. 1993;83(5):533-7.

Passey T, Xu X. Chapter 1. Epidemiology and management of apple scab. In: Integrated management of diseases and insect pests of tree fruit. Burleigh Dodds; 2019. p. 3-14.

Passey TAJ, Robinson JD, Shaw MW, Xu X-M. The relative importance of conidia and ascospores as primary inoculum of Venturia inaequalis in a southeast England orchard. Plant Pathol. 2017;66(9):1445-51.

Patocchi A, Wehrli A, Dubuis P-H, Auwerkerken A, Leida C, Cipriani G, et al. Ten years of VINQUEST: first insight for breeding new apple cultivars with durable apple scab resistance. Plant Dis. 2020. https://doi.org/10.1094/ PDIS-11-19-2473-SR.

Peever TL, Liu Y-C, Cortesi P, Milgroom MG. Variation in tolerance and virulence in the chestnut blight fungus-hypovirus interaction. Appl Environ Microbiol. 2000;66(11):4863-9.

Pfleiderer P, Menke I, Schleussner C-F. Increasing risks of apple tree frost damage under climate change. Clim Change. 2019;157(3):515-25.

Phillips AJL, Alves A, Abdollahzadeh J, Slippers B, Wingfield MJ, Groenewald JZ, et al. The Botryosphaeriaceae: genera and species known from culture. Stud Mycol. 2013;76(1):51-167.

Pirlak L, Turan M, Sahin F, Esitken A. Floral and foliar application of plant growth promoting rhizobacteria (PGPR) to apples increases yield, growth, and nutrient element contents of leaves. J Sustain Agric. 2007;30(4):145-55.

Purin S, Filho OK, Stürmer SL. Mycorrhizae activity and diversity in conventional and organic apple orchards from Brazil. Soil Biol Biochem. 2006;38(7):1831-9.

Ramírez F, Kallarackal J. Climate change and chilling requirements. In: Ramirez F, Kallarackal J, editors. Responses of fruit trees to global climate change. Cham: Springer International Publishing; 2015. p. 31-34. (SpringerBriefs in Plant Science).

Rigling D, Prospero S. Cryphonectria parasitica, the causal agent of chestnut blight: invasion history, population biology and disease control. Mol Plant Pathol. 2018;19(1):7-20.

Rumberger A, Yao S, Merwin I, Nelson E, Thies J. Rootstock genotype and orchard replant position rather than soil fumigation or compost amendment determine tree growth and rhizosphere bacterial community composition in an apple replant soil. Plant Soil. 2004;264:247-60.

Saga Robotics. 2020. Effective powdery mildew control without fungicides using Thorvald light treatment. Saga Robotics Ltd. https://sagaroboti cs.com/wp-content/uploads/Strawberry-Polytunnel-Light-Treatment2021-8-pages.pdf.

Santoiemma G, Tamburini G, Sanna F, Mori N, Marini L. Landscape composition predicts the distribution of Philaenus spumarius, vector of Xylella fastidiosa, in olive groves. J Pest Sci. 2019;92(3):1101-9.

Saville R, Olivieri L. Chapter 4. Fungal diseases of fruit: apple cankers in Europe. In: Integrated management of diseases and insect pests of tree fruit. Burleigh Dodds; 2019. p. 59-83.

Schiewe A, Mendgen K. Identification of antagonists for biological control of the post-harvest pathogens Pezicula malicorticis and Nectria galligena on apples. J Phytopathol. 1992;134(3):229-37. 
Slippers B. The plant disease pyramid: the relevance of the original vision of plant pathology in 2020. S Afr J Sci. 2020;116(11/12):9011.

Soil Association. Soil Association Standards: Farming and Growing. Version 18.6. 2021. https://www.soilassociation.org/media/15931/farming-andgrowing-standards.pdf 2021.

Stevens C, Wilson CL, Lu JY, Khan VA, Chalutz E, Droby S, et al. Plant hormesis induced by ultraviolet light-C for controlling postharvest diseases of tree fruits. Crop Prot. 1996;15(2):129-34.

Su C-C, Deng W-L, Jan F-J, Chang C-J, Huang H, Chen J. Draft genome sequence of Xylella fastidiosa pear leaf scorch strain in Taiwan. Genome Announc. 2014;2(2)

Swinburne TR. European canker of apple (Nectria galligena). Rev Plant Pathol. 1975;54(10):787-99.

Tilston EL, Deakin G, Bennett J, Passey T, Harrison N, Fernández F, et al. Effect of fungal, oomycete and nematode interactions on apple root development in replant soil. CABI Agric Biosci. 2020;1 (1):14.

van Leeuwen GCM, Stein A, Holb I, Jeger MJ. Yield loss in apple caused by Monilinia fructigena, and spatio-temporal dynamics of disease development. Eur J Plant Pathol. 2000;106(6):519-28.

van Schoor L, Denman S, Cook NC. Characterisation of apple replant disease under South African conditions and potential biological management strategies. Sci Hortic. 2009;119(2):153-62.

VandeWeg WE. Screening for resistance to Nectria galligena Bres. in cut shoots of apple. Euphytica. 1989;42(3):233-40.

Walter M, Campbell RE, Amponsah NT, Turner L, Rainham D, Kerer U, et al. Can biological products control Neonectria ditissima picking wound and leaf scar infections in apples? N Z Plant Prot. 2017:70:63-72.

Wang L, Mazzola M. Interaction of Brassicaceae seed meal soil amendment and apple rootstock genotype on microbiome structure and replant disease suppression. Phytopathology. 2019;109(4):607-14.

Wang Y, Pan F, Wang G, Zhang G, Wang Y, Chen X, et al. Effects of biochar on photosynthesis and antioxidative system of Malus hupehensis Rehd. seedlings under replant conditions. Sci Hortic. 2014;175:9-15.
Wang Y, Fu F, Li J, Wang G, Wu M, Zhan J, et al. Effects of seaweed fertilizer on the growth of Malus hupehensis Rehd. seedlings, soil enzyme activities and fungal communities under replant condition. Eur J Soil Biol. 2016;75:1-7.

Weber RWS, Børve J. Infection biology as the basis of integrated control of apple canker (Neonectria ditissima) in Northern Europe. CABI Agric Biosci. 2021;2(1):5.

Winkelmann T, Smalla K, Amelung W, Baab G, Grunewaldt-Stöcker G, Kanfra $X$, et al. Apple replant disease: Causes and mitigation strategies. Curr Issues Mol Biol 2019;89-106.

Xu X. Modelling and forecasting epidemics of apple powdery mildew (Podosphaera leucotricha). Plant Pathol. 1999;48(4):462-71.

$\mathrm{Xu} X$. The role of endophytes in affecting symptom development of European apple canker caused by Neonectria ditissima. UK Research \& Innovation BB/P007899/1. 2021. https://gtr.ukri.org/project/COFFC65C-DF4D-44C2AC7C-196A749C2FEB.

Xu X, Butt DJ. PC-based disease warning systems for use by apple growers. EPPO Bull. 1993;23(4):595-600

Xu X, Berrie A. A review of the current knowledge of apple replant disease. Agriculture and Horticulture Development Board; 2018

Xu X, Robinson JD. Epidemiology of brown rot (Monilinia fructigena) on apple: infection of fruits by conidia. Plant Pathol. 2000;49(2):201-6.

Yaegashi H, Kanematsu S, Ito T. Molecular characterization of a new hypovirus infecting a phytopathogenic fungus Valsa Ceratosperma. Virus Res. 2012;165(2):143-50

Zhang Z, Chen Q, Yin C, Shen X, Chen X, Sun H, et al. The effects of organic matter on the physiological features of Malus hupehensis seedlings and soil properties under replant conditions. Sci Hortic. 2012;146:52-8.

\section{Publisher's Note}

Springer Nature remains neutral with regard to jurisdictional claims in published maps and institutional affiliations.
Ready to submit your research? Choose BMC and benefit from:

- fast, convenient online submission

- thorough peer review by experienced researchers in your field

- rapid publication on acceptance

- support for research data, including large and complex data types

- gold Open Access which fosters wider collaboration and increased citations

- maximum visibility for your research: over 100M website views per year

At BMC, research is always in progress.

Learn more biomedcentral.com/submissions 